\title{
Effect of sulphachloropyrazine on antioxidative systems in blood and liver of broilers
}

\author{
Ljiljana M. Kostadinović1, Sava T. Pavkov², Jovanka D. Lević3 ${ }^{3}$ Tamara A. Galonja- \\ Coghill $^{1}$, Gordana K. Dozet ${ }^{1}$, Nenad Č. Bojat ${ }^{1}$
}

${ }^{1}$ Faculty of Biofarming, Megatrend University, Bačka Topola, R. Serbia

${ }^{2}$ Institute for Medicinal Plants Research "Dr Josif Pančić”, Belgrade, R. Serbia

${ }^{3}$ Institute for Food Technology in Novi Sad, "FINS", Novi Sad, R. Serbia

Received June 3, 2009

Accepted October 26, 2010

\begin{abstract}
This report describes the effects of therapeutic doses of coccidiocid sulphachloropyrazine on enzymatic and non-enzymatic antioxidative systems in haemolysed blood and liver homogenate from broilers (glutathione, glutathione-reductase, glutathione-peroxidase, peroxidase, superoxidedismutase, xantine-oxidase and lipid peroxidation). The in vivo investigation was carried out on 120 heavy-line broilers (Arbor acres) of both sexes. One-day-old broilers were randomly distributed into 2 groups, each numbering 60 individuals of both sexes: Group 1 - control group; Group 2 - group of broilers inoculated with laboratory derived coccidia species on the $21^{\text {st }}$ day-ofage. When symptoms of coccidiosis appeared ( $30^{\text {th }}$ day-of-age), blood sampling and decapitation of 20 chickens were carried out (Group 2a). The remaining broilers were treated with therapeutic doses of sulphachloropyrazine (60 ppm). Decapitation of 20 chickens was carried out after the therapy was concluded ( $38^{\text {th }}$ day-of-age - Group 2 b). Infection of broilers with coccidia intensified free radical processing in haemolysed blood and liver homogenate. This was evident from the increased levels of lipid peroxidation and the catalytic activity of almost all examined enzymes (SOD, GSHPx and Px). Therapeutic doses of sulphachloropyrazine inhibited free-radical activity induced by disease and establishing of physiological values of lipid peroxidation and catalase activity of examined enzymes.
\end{abstract}

Coccidiocid, Eimeria, enzymatic, non-enzymatic antioxidative systems, therapy

Coccidiosis is an infectious disease of the digestive tract which is most frequent in poultry, causing prolonged fattening, slower feed conversion and increased mortality (Jenkins et al. 2008). The disease is caused by protozoas from the genera of Eimeria, Isospora and Cryptospora, and it is manifested by damage of the intestinal epithelial cells, less frequently the bile duct and renal tubuli (Perry and Long 1987). If coccidiosis is manifested in its clinical form, the sulphonamide-based derivatives, i.e. the derivatives of p-aminobenzolsulphonic acid are used for treatment (Arakawa et al. 1991; Katzung 1995). Sulphachloropyrazine-4-amino-N(choropyrazinyl)-monosodium monohydrate (active substance of the drug "Esb $30 \%$ ") is a sulphonamide of a wide spectrum of action, (Bevill 1988).

For the diagnostics of blood and organ diseases, catalytic activity of enzymes in erythrocytes and liver is most commonly monitored. Erythrocytes are directly exposed to molecular oxygen; their plasma membrane has high concentrations of polyunsaturated fatty acids and an anionic channel specific for single oxygen. Furthermore, erythrocytes contain a high concentration of haemoglobin that is exposed to antioxidation. Erythrocytes have a highly effective system of protection from free radicals: they contain all the enzymes of antioxidative protection and a high level of glutathion (Jovanović 1993). The liver is an organ with a central metabolic role in the organism, often referred to as "the main laboratory" since it performs major detoxification functions. For this reason the liver is the prime target for the study of the metabolism of xenobiotics (Popović 1988). Antioxidant enzymes counteract exessive formation and harmful effects of reactive oxygen

Address for correspondence:

Dr. Ljiljana Kostadinović

Maršala Tita 39, 24300 Bačka Topola

R. Serbia 
metabolites (Cotgreave et al. 1988). For example, superoxide-dismutase (SOD) catalyzes the conversion of superoxide anion radical to $\mathrm{H}_{2} \mathrm{O}_{2}$, catalase reduces $\mathrm{H}_{2} \mathrm{O}_{2}$ to water, while gluthatione-peroxidase (GSH-Px) acts in conjuction with other enzymes to reduce $\mathrm{H}_{2} \mathrm{O}_{2}$ and to terminate lipid peroxidation. The interaction of lipid peroxidation and activity of superoxide dismutase has been studied by some authors in houseflies (Allen et al. 1983; Sohal et al. 1984), Drosophila and mice (Miquel 1983), frogs (Lopez-Torres et al. 1993) and in broiler chickens (Kostadinović et al. 2001). Enkvetchakul et al. (1995) analysed the age relationship for hepatic and whole blood gluthatione in male broiler chickens.

The aim of this study was to determine the effect of therapeutic doses of coccidiostat sulphachloropyrazine on the catalytic activity of the important enzyme of oxidative protection in blood haemolysates and liver homogenates of healthy and artificially infected broilers. Examination of the catalytic activity of oxidative defense enzymes in blood and liver of broilers and assessment of their physiological values can be used for early diagnostics of coccidiosis.

\section{Materials and Methods}

Experiments in vivo were performed on 120 broilers of the heavy line Arbor Acres, of both sexes. One-day-old broilers, randomly selected, were divided into two groups of 60 individuals. One group of broilers uninfected with coccidia was used as control (Group 1). Blood sampling and decapitation of 40 chickens was carried out on the $42^{\text {nd }}$ day-of-age.

The second group of broilers was inoculated with laboratory strains of coccidia. Inoculation of 21-day-old broilers was performed by oral application of $1 \mathrm{~cm}^{3}$ of coccidial suspension containing the mixture of newly isolated oocysts of E. tenella (5000 oocysts), E.mitis (5000 oocysts), and E. necatrix genus (10 000 oocysts). Nine days later $\left(30^{\text {th }}\right.$ day-of-age), first clinical signs of disease appeared, chickens were bristling, showed decreased food conversion, white mucous and later bloody diarrhea appeared and appetite decreased etc. Blood sampling and decapitation of 20 chickens were carried out (Group 2a). The remaining broilers were subsequently treated with therapeutic doses of anticoccidial preparation based on sulphachloropyrazine (active component of the drug Esb $_{3} 30 \%$ ): $20 \mathrm{~g}$ of the drug per $100 \mathrm{dm}^{3}$ of drinking water (which corresponds to $60 \mathrm{ppm}$ of sulphachloropyrazine) for 8 days ( 3 days therapy, 2 days break, 3 days therapy). Blood sampling and decapitation of other 20 chickens were carried out after the therapy was finished at $38^{\text {th }}$ day-of-age (Group 2b). During the experiments, chickens were regularly observed, autopsies were performed and all findings were carefully recorded. Concentrations of haemoglobin, necessary for the expression of the enzymatic activities in haemolysed blood, were determined using commercial test ("Dialab", Vienna, Austria) on a spectrophotometer (Multiscan MCC 340, Finland). The protein content was determined by the modified method of Gornall and Bardwall (1949). In haemolysed blood and homogenized liver, glutathione content, products of lipid peroxidation and the activities of anti-oxidant enzymes (SOD, GSHR, GSHPx, Px and XOD) were determined.

Preparation of blood haemolysate

Blood was collected by heart puncture of broilers into heparinized test tubes. After centrifuging (10 min at $1372 \mathrm{~g}$ and $277 \mathrm{~K}$ ) and plasma removal, the erythrocytes were rinsed $3 \times$ in saline. The resulting erythrocyte pellet was suspended in an equal volume of double distilled water and vortexed. After incubation for $1 \mathrm{~h}$ at room temperature, the haemolysate was centrifuged for $15 \mathrm{~min}$ at $1372 \mathrm{~g}$ and supernatant aliquoted for further analysis (Kostadinović 1998).

Preparation of liver homogenate

The excised liver was perfused to eliminate blood and total mass was determined. One gram of the tissue was minced with scissors and homogenized in an ultraturax in 3 volumes of isotonic buffer $\left(0.05 \mathrm{~mol} \cdot \mathrm{dm}^{-3} \mathrm{tris}-\mathrm{HCl}\right.$, $0.25 \mathrm{~mol} \cdot \mathrm{dm}^{-3}$ sucrose, $\left.\mathrm{pH}=7.5\right)$. The homogenate was filtered through gauze into ice-cold tubes and aliquoted for further analysis (Kostadinović 1998).

Sample preparation for glutathione (GSH) determination

In freshly prepared haemolysate, proteins were separated by adding half the volume of $10 \%$ sulphosalicylic acid and centrifugation at $2800 \mathrm{~g}$, for $5 \mathrm{~min}$, at $277 \mathrm{~K}$. The supernatant was stored at $277 \mathrm{~K}$, without freezing, and GSH determined within $24 \mathrm{~h}$. The same procedure was applied for liver homogenate.

Determination of enzymatic activity

The superoxide dismutase (SOD) activity was determined by the spectrophotometric method based on the inhibition of adrenaline reduction to adrenochrome at $\mathrm{pH}=10.2$ (Kostadinović et al. 2001).

The glutathione peroxidase (GSH Px) activity was determined by spectrophotometric measurement of absorbance at $412 \mathrm{~nm}$ with cumenhydroperoxide as the substrate (Chin et al. 1976). Based on the method of 
Glatzle et al. (1974), the glutathione reductase (GSHR) activity was determined from the rate of NADPH oxidation, monitored by the absorbance at $340 \mathrm{~nm}$.

Lipid peroxidation (LPx) was determined by thiobarbituric acid (TBA-test). The oxidation of cellular membrane lipids was measured via reaction of lipid peroxides with thiobarbituric acid (Buege and Aust 1978).

The determination of peroxidase (Px) activity was based on the catalytic oxidation of guayacole by hydrogen peroxide as an electron acceptor (Simmon et al. 1974).

The reaction of xanthine oxidation touric acid was used for determination of XOD activity (Bergmayer 1974). Spectrophotometric measurement was performed in $0.1 \mathrm{mmol} \cdot \mathrm{dm}^{-3}$ phosphate buffer, $\mathrm{pH}=7.5$, at $295 \mathrm{~nm}$.

The glutathione (GSH) content in the blood haemolysate and the liver homogenate was determined from the amount of sulphhydryl residues by means of Ellmann's reagent (Rollinger et al. 2004). The erythrocyte content of GSH was determined by the modified method of Beutler et al. (1963) and in the liver homogenates by the modified method of Ellmann (Rollinger et al. 2004).

\section{Statistics}

Differences between means were evaluated at different levels of significance $(p<0.05, p<0.01, p<0.001)$ using repeated measures analysis of variance (Sokal and Rohlf 1981).

\section{Results}

The GSH and LPx concentrations and enzymatic activity found in blood haemolysates from the control group ( $42^{\text {nd }}$ day-of-age) and the experimental group ( $2 \mathrm{a}-30^{\text {th }}$ day-ofage and $2 b-38^{\text {th }}$ day-of-age) are shown in Table 1 . Significant increase in the content of GSH and higher catalytic activity of almost all examined enzymes (GSHPx and Px) in blood haemolysates of infected broilers (Group 2a) was found, while the increase in the content of LPx and SOD activity was highly significant $(p<0.001)$. The only exception was the catalytic activity of XOD which showed a significant reduction in group of infected broilers (Group 2a) compared to the control (Group 1). Sulphachloropyrazine therapy (Group 2b) resulted in significant induction of GSHPx and Px catalase activity, as well as significant inhibition of GSHR and XOD catalase activity in blood haemolysates of infected and consequently treated broilers compared to the control group. A tendency for establishing physiological values of LPx content and catalase activity of SOD was observed in blood haemolysates of broilers after sulpachloropyrazine therapy.

The content of GSH and LPx and the catalytic activity of selected enzymes of the anti-oxidative defense system found in the liver homogenates of the control

Table 1. Glutathione(GSH) and lipid peroxidation (LPx) content and the activity of glutathione peroxidase (GSHPx), peroxidase (Px), superoxide dismutase (SOD), glutathione reductase (GSHR) and xanthine oxidase (XOD) in blood haemolysates obtained from chicken broilers

\begin{tabular}{lccc}
\hline Indicator & Group 1 - Control & $\begin{array}{c}\text { Experimental groups } \\
\text { 2a - infected, prior to } \\
\text { therapy }\left(30^{\text {th }} \text { day-of-age }\right)\end{array}$ & $\begin{array}{c}2 \mathrm{~b}-\text { after sulphachloropyrazine } \\
\text { therapy }\left(38^{\text {th }} \text { day-of-age }\right)\end{array}$ \\
\hline $\mathrm{GSH}(\mu \mathrm{mol} / \mathrm{g} \mathrm{Hb})$ & $8.13 \pm 1.97$ & $6.72 \pm 2.11^{\mathrm{c}}$ & $9.31 \pm 1.61^{\mathrm{C}}$ \\
$\mathrm{LPx}(\mu \mathrm{mol} / \mathrm{g} \mathrm{Hb})$ & $0.22 \pm 0.06$ & $5.34 \pm 0.19^{\mathrm{a}}$ & $0.30 \pm 0.13^{\mathrm{A}}$ \\
$\mathrm{GSHPx}(\mu \mathrm{mol} / \mathrm{g} \mathrm{Hb} \mathrm{min})$ & $6.72 \pm 2.08$ & $12.92 \pm 6.75$ & $14.14 \pm 2.10^{\mathrm{b}}$ \\
$\mathrm{Px}(\mu \mathrm{mol} / \mathrm{g} \mathrm{Hb} \mathrm{min})$ & $82.92 \pm 2.39$ & $95.17 \pm 5.78$ & $99.53 \pm 18.39^{\mathrm{b}}$ \\
$\mathrm{SOD}(\mu \mathrm{mol} / \mathrm{g} \mathrm{Hb} \min )$ & $24.72 \pm 5.83$ & $61.35 \pm 20.27^{\mathrm{a}}$ & $20.67 \pm 3.80^{\mathrm{A}}$ \\
$\mathrm{GSHR}(\mu \mathrm{mol} / \mathrm{g} \mathrm{Hb} \min )$ & $16.04 \pm 6.40$ & $15.92 \pm 6.08$ & $10.12 \pm 2.80^{\mathrm{b}, \mathrm{B}}$ \\
$\mathrm{XOD}(\mu \mathrm{mol} / \mathrm{g} \mathrm{Hb} \min )$ & $20.29 \pm 9.35$ & $14.96 \pm 6.58^{\mathrm{b}}$ & $10.93 \pm 2.97^{\mathrm{a}, \mathrm{B}}$ \\
\hline
\end{tabular}

Data are mean values \pm SD for 40 determinations for the control group and 20 determinations for groups $2 \mathrm{a}$ and $2 \mathrm{~b}$ of broilers

Significance of difference between groups: ${ }^{\mathrm{a}, \mathrm{A}} p<0.001 ;{ }^{\mathrm{b}, \mathrm{B}} p<0.01 ;{ }^{\mathrm{c}, \mathrm{C}} p<0.05$

$\mathrm{a}, \mathrm{b}, \mathrm{c}-$ Significance of difference between the control group (1) and experimental group of broilers ( $2 \mathrm{a}$ and $2 \mathrm{~b})$

A, B, C - Significance of difference between groups of infected broilers before (2a) and after treatment with sulphachloropyrazine (2b).

$\mathrm{Hb}$ - Haemoglobine 
(Group 1) and experimental groups ( $2 \mathrm{a}-30^{\text {th }}$ day-of-age and $2 \mathrm{~b}-38^{\text {th }}$ day-of-age) are shown in Table 2.

In the liver homogenates of infected broilers (before sulphachloropyrazyne therapy Group 2a) the contents of GSH and catalytic activity of GSHPx were significantly higher than control values, whereas the activities of Px and GSHR were reduced.

Table 2. Glutathione (GSH) and lipid peroxidation (LPx) content and the activity of glutathione peroxidase (GSHPx), peroxidase (Px), superoxide dismutase (SOD), glutathione reductase (GSHR) and xanthine oxidase $(\mathrm{XOD})$ in liver homogenates

\begin{tabular}{lccc}
\hline Indicator & Group 1 - Control & $\begin{array}{c}\text { Group 2a } \\
- \text { infected, prior to } \\
\text { therapy (30 }\end{array}$ & $\begin{array}{c}\text { Group 2b - after } \\
\text { sulphachloropyrazine } \\
\text { therapy (38 }\end{array}$ \\
\hline GSH (nmol/mg day-of-age)
\end{tabular}

Data are mean values \pm SD for 40 determinations for the control group and 20 determinations for groups $2 \mathrm{a}$ and $2 \mathrm{~b}$ of broilers

Significance of difference between groups: ${ }^{\mathrm{a}, \mathrm{A}} p<0.001$; ${ }^{\mathrm{b}, \mathrm{B}} p<0.01$; ${ }^{\mathrm{c}, \mathrm{C}} p<0.05$

$a, b, c-$ Significance of difference between the control group (1) and experimental groups of broilers (2a and $2 b)$

A, B, C - Significance of difference between groups of infected broilers before (2a) and after treatment with sulphachloropyrazine $(2 b)$.

$\mathrm{Hb}$ : Haemoglobine

Comparison of the results from Table 1 and 2 showing the anti-oxidative protection in haemolysed blood and liver homogenates of infected broilers (before sulphachloropyrazyne therapy- Group 2a) indicates good correlation in terms of the content of GSH and the catalytic activities of GSHR and XOD. Reduction of the catalytic activity of GSHR in the liver homogenates of infected chickens was significant, whereas the slight reduction of this activity in the blood haemolysates was without significance. The reduction of the activity of XOD in blood haemolysates and liver homogenates of infected chickens was significant only in the blood haemolysates.

Mortality rate in the control group up to the $42^{\text {nd }}$ day-of-age was $6.6 \%$. In the experimental group, the mortality rate of $6.0 \%$ was till the $21^{\text {st }}$ day-of-age. None of the therapeutically treated broilers died.

\section{Discussion}

The most likely explanation for the observed phenomena presented in Table 1 is that the pathological alterations intensify free radical processes by stimulating catalytic activities of enzymes involved in the anti-oxidative protection, Px and SOD. However, during the disease, lipolysis from the lipid depots is increased due to smaller food intake and exhaustion of the organism by diarrhea, which leads to intensification of free radical processes and formation of larger quantities of lipid peroxides in blood. Newly formed lipid peroxides and their degradation products are transported by blood stream to inactive organs and tissues having a toxic effect on them and generating cellular membrane damages. The organism then activates its antioxidative protection system. Induction of catalytic activity of superoxide dismutase is expected and in agreement with literature 
data (Mezes et al. 1992). Simultaneously with the increased risk of peroxidation of lipids in blood, there is an increase in the enzymatic activity of GSHPx.

When Eimeria enter the digestive system, different developmental stages secrete specific metabolites that may be absorbed and induce changes in the enzymatic activity of the antioxidative protective system in a variety of tissues.

Inhibition and induction of enzyme activity in liver homogenates of infected and sulphachloropyrazine-treated broilers tended to eliminate harmful free-radical activity induced by the disease and to establish physiological values characteristic for the untreated group of broilers. Observed changes showed positive therapeutic effects of the administered coccidiocid sulphachloropyrazine.

Sulphachloropyrazine has a greater positive effect on the antioxidative system of erythrocytes. This may be caused by producing more significant changes of these biochemical indicators compared to liver homogenates, which can be explained by larger antioxidative capacity of liver and larger exposure of erythrocytes to the oxidative stress (Hunter and Mohamed 1986).

Investigation of catalase activity of enzymes responsible for the antioxidative protection of broilers, and application of simple and fast biochemical analyses can lead to correct and early diagnosis of coccidiosis.

\section{References}

Allen RG, Farmer KJ, Sohal RS 1983: Effect of catalase inactivation on levels of inorganic peroxides, superoxide dismutase, glutathione, oxygen consumption and life span in adult houseflies (Musca domestica). Biochem $\mathrm{J}$ 216: $503-506$

Arakawa A, Tanaka Y, Baba E, Fukata T 1991: Effects of clopidol on sporulation and infectivity of Eimeria tenella oocysts. Vet Parasitol 38: 55-60

Bergmayer HU 1974: Methods of enzymatic analysis. Verlag-Chemie, GmbH, Weinhem

Beutler E, Duron O, Kelly B 1963: Improved method for the determination of blood glutathione. J Lab Clin Med 61: $882-885$

Bevill RF 1988: Sulphonamides. In: Booth NH and McDonald LE (Eds.) Veterinary Pharmacology and Therapeutics. 6. Ed. Iowa State University Press: Ames, Iowa: 785-795

Buege JA, Aust SD 1978: Microsomal Lipid Peroxidation - in: Fleischer S, Packer L: Methods in Enzymology. New York: Academic Press. 52, pp: 302-310

Chin PTV, Stults FH, Tapell AP 1976: Purification of rat lung soluble glutathione peroxidase. Biochem Biophys Acta 445: 558-666

Cotgreave IA, Moldeus P, Arrenius S 1988: Host biochemical defense mechanisms against prooxidants. Annu Rev Pharmacol Toxicol 28: 189-212

Enkvetchakul B, Anthony NB, Botje WG 1995: Liver and blood glutathione in male broiler chickens, turkeys and quail. Poultry Sci 74: 885-889

Glatzle D, Vulleumier JP, Weber F, Decker K 1974: Glutathione reductase test with whole blood-aconvenient procedure for the assessment of the riboflavin status in humans. Experienta 30: 565-638

Hunter M, Mohamed J 1986: Plasma antioxidant and lipid peroxidation products in Duchenne muscular dystrophy. Chim Acta 155: 123-132

Jenkins M, Allen P, Wilkins G, Klopp S, Miska K 2008. Eimeria praecox infection ameliorates effects of Eimeria maxima infection in chickens. Vet Parasitol 155: 10-14

Jovanović A 1993: Effect of Selenium on antioxidative system carp's erythrocytes and liver. PhD Thesis, Univ. Novi Sad

Katzung BG 1995: Basic and clinical pharmacology. $6^{\text {th }}$ ed., Prentice-Hall International Inc., San Francisco, pp. 716-722

Kostadinović LJ 1998: Uticaj kokcidiostatika na biohemijske parametre brojlera i određivanje njihovih rezidua u tkivima (in Serbian), Effect of coccidiosis on broilers parameters and determination residues of coccidiostatics in broiler's tissue. PhD Thesis, Nature-mathematics faculty, Univ. Novi Sad, Novi Sad, pp. 82-98

Kostadinović LJ, Popović M, Pavkov S, Dimitrijević S, Stevanović Đ 1998: Effect of coccidiosis on the enzymatic and non-enzymatic antioxidative systems in broilers. Acta Vet Belgrade 5-6: 323-330

Kostadinović LJ, Pavlovski Z, Pavkov S 2001: Effect of amprolium on the lipid peroxidation and the activity of superoxide dismutase in broilers blood and liver. Arch Geflugelk 65: 118-122

Lopez-Torres M, Perez-Campo R, Fernandez A, Barba C, Barja De Quiroga G 1993: Brain glutathione reductase induction increases early survival and decreases lipofuscin accumulation in aging frogs. J Neurosci Res 34: $233-242$ 
Mezes M, Salyi G, Banhidi GY, Szeberenyi SZ 1992: Effect of acute salinomycin-tiamulin toxicity on the lipid peroxide and antioxidant status of broiler chicken. Acta Vet Hung 40: 251-257

Miquel J 1983: Determination of biological age in antioxidant-treated Drosophilla and mice. In Intervention in the aging process, Part B: Basic research and preclinical screening (Edited by LISS AR) New York, pp. 317-358

Radostits OM, Blood DC, GAY CC 1994: Veterinary medicine a textbook of the disease of cattle sheep goat and horses $8^{\text {th }}$ Edition. Paston press 1td, London, Norfolk, UK pp. 1469-1499

Rollinger JM, Hornick A, Langer T, Stuppner H, Prast H 2004: Acetylcholinesterase inhibited activity of scopolin and scopoletin discovered by virtual screening of natural products. J Med Chem 47: 6248-6254

Sohal RS, Farmer K, Allen RG, Ragland SS 1984: Effects of diethyldithiocarbamate of lifespan, metabolic rate, superoxide dismutase, catalase, inorganic peroxides and glutathione in the adult male housefly $\mathrm{Musca}$ domestica. Mech Ageing Dev 24: 175-183

Sokal RR, Rohlf FJ 1981. Biometry. W. H. Freemen, San Francisco, 859 p.

Simmon LM, Fatrai Z, Jonas De, Matkovics B 1974: Study of metabolism enzymes during the development of Phascoulus vulgaris. Biochem Physiol Pflauz 166: 389-393 